\title{
IM Online: Instant Messaging Use Among College Students
}

\section{Andrew J. Flanagin}

Research on computer-mediated communication (CMC) has thus far largely overlooked instant messaging (IM), an extremely popular, and increasingly important, form of CMC. This study examines the most prevalent motivations for using IM within what is currently among the largest demographic groups utilizing this tool, college students. Data from 271 students are used to assess current motivations for IM use, its relative (dis)advantages over other communication channels, and its potential displacement of other technologies. Findings indicate that IM usage parallels factors found in other research, although important differences emerge within cross-media comparisons. In addition, respondents exhibited a high capacity for multi-tasking in IM conversations, and results suggest displacement effects, particularly of email by IM. Overall, results of this study shed considerable light on the use of IM among those users who will become increasingly important over time for understanding IM use in the contemporary media environment.

Keywords: Instant messaging; Computer-mediated communication; CMC; Electronic technology; New technology; Uses and gratifications

In pace with the rapid diffusion of the Internet, research on computer-mediated communication (CMC) in the last decade is abundant and rich. However, CMC research has thus far emphasized the study of electronic mail over other forms of $\mathrm{CMC}$, in spite of the diversity of online communication tools in use today. The result is that extremely popular, and increasingly important, forms of CMC have not yet received the research attention they warrant. To fill this research void, this study examines the most prevalent motivations for using an increasingly important CMC tool - instant messaging - within what is currently among the largest demographic groups utilizing this tool, college students.

\footnotetext{
Andrew Flanagin (PhD, 1996, Annenberg School for Communication, University of Southern California) is an Associate Professor in the Department of Communication at the University of California at Santa Barbara. The author would like to thank Rachel Medel for her substantial contributions to the execution of this project. Correspondence to: Andrew J. Flanagin, Department of Communication, University of California, Santa Barbara, Santa Barbara, CA 93106, USA (Tel: +805-893-7892; Email: flanagin@comm.ucsb.edu).
} 


\section{Instant Messaging}

Instant messaging ("IM")[1] has become enormously popular. The four largest IM providers combined boast 270 million users worldwide (Graham, 2003), who send an astounding 582 billion messages daily (Radicati Group, 2003). Forrester Research estimates that $45 \%$ of those who are online in North America use IM at least once weekly, and among those $90 \%$ use it daily (cited in Mello, 2002). In the USA, IM usage has grown faster than email usage (Oliva, 2003), by approximately $33 \%$ from 2000 to 2002 (Pew Research, 2003), resulting in between 52 (Pew Research, 2003) and 60 million IM users in the USA (Whelan, 2001). Its considerable utility has also resulted in increased corporate usage (Rennecker \& Godwin, 2003; Swartz, 2003), with the number of workplace IM users estimated at between 13 and 17 million users (Rennecker \& Godwin, 2003). The net result of this skyrocketing popularity is that IM is currently used by roughly half as many people as email is today (Pew Research, 2003).

IM use is currently dominated by younger people (Pew Research, 2003). Among 12-17 year olds, $74 \%$ of those who are online report using IM, vs. $44 \%$ of online adults, resulting in 13 million US teenage IM users, among whom 20\% report that IM is the main tool they use to communicate with their friends (Pew Research, 2001). In addition, nine of the top 15 web sites among teens feature instant messaging tools and services (Nielsen//NetRatings, 2002b) and three of the top five Internet applications among all users are IM-related (Nielsen//NetRatings, 2002a). Estimates suggest that approximately $30 \%$ of IM users are between the ages of 18 and 29 (Radicati Group, 2003; Whelan, 2001), as a result of widespread Internet access and typically strong adopters of innovative technologies among this age group. Thus, people of typical college age constitute a considerable and important population of IM users.

\section{The Nature of IM Usage Among College Students}

IM is used to fulfill a wide variety of needs, such as to keep in touch with others who live far away or whom you do not have sufficient time to see in person, to give and receive information, and because it makes communication fast, easy, and convenient (Ramirez, Dimmick, \& Lin, 2004). In addition, various forms of identity manipulation in IM have been used for self-exploration, as an aid to overcome shyness, and to facilitate the formation of social relationships (Peter, Schouten, \& Valkenburg, 2004). Finally, IM is used to express affection, to be fashionable, and for entertainment, relaxation, inclusion, sociability, and escape (Leung, 2001). Given these myriad applications, theoretical perspectives capable of assessing a diversity of uses need to be invoked to understand IM usage behaviors.

Accordingly, uses and gratifications (U\&G) theory has been advocated for examining new technologies, due also to the theory's strength in assessing new media given their specific technical attributes (Ruggiero, 2000). Indeed, researchers 
have recently begun to apply uses and gratifications to study media use behaviors with newer technologies (Flaherty, Pearce, \& Rubin, 1998; Kaye, 1998; Kaye \& Johnson, 2002; Leung, 2001; Metzger \& Flanagin, 2002; Ramirez et al., 2004; Rubin \& Rubin, 1985; Perse \& Courtright, 1993; Tewksbury \& Althaus, 2000).

Uses and gratifications (Katz, Blumler, \& Gurevitch, 1974) is a tradition of media research that focuses on the needs of individuals which they seek to gratify through media use. It views individuals as purposive, active participants who select media based on social and psychological needs (Rubin, 2002). Katz, Gurevitch, and Haas (1973) specify that each medium provides a unique combination of features that makes it suitable for gratifying certain needs. Objectives of uses and gratifications research are to explain how media satisfy needs, to understand media use motives, and to explore outcomes stemming from use.

The functional images of media distinguish communication technologies according to their most salient features and uses (i.e., functions). A medium's functional image is composed of both its "functional alternatives" (media that satisfy similar needs) and its "normative image" (widely shared perceptions of a medium's usage) (see Lichtenstein \& Rosenfeld, 1983, 1984; Perse \& Courtright, 1993; Rubin, 2002). Consequently, functional images can be understood through an examination of (a) the primary needs fulfilled by a medium and (b) the relative advantage of a medium over alternative channels. In view of recent additions to the communication technology landscape, coupled with substantial IM usage among college age individuals, an evaluation of the functional image of IM is a timely pursuit, as addressed in the following research questions:

RQ1: What are the primary needs fulfilled by IM among college students?

RQ2: What are some of IM's relative (dis)advantages in fulfilling these needs over other media?

Concurrency, or a medium's ability to support distinct communication events simultaneously without detracting from others, has been proposed as a dimension contributing to the perceived "richness" of a communication medium (Valacich, Paranka, George, \& Nunamaker, 1993). Indeed, the ability to carry on simultaneous conversations within IM is often cited as a feature of the tool, in spite of perspectives that argue that information overload may result in reduced satisfaction (Lee \& Lee, 2004). To assess the effect of concurrent conversations within IM, Research Question 3 asks:

RQ3: How does carrying on multiple conversations simultaneously in IM affect communication satisfaction?

The use of new communication technologies may enhance, weaken, or have no effect on the use of existing media. Flanagin and Metzger (2001) found that newer media tend to fulfill similar roles as traditional technologies and Kayany and Yelsma (2000) found that the entertainment functions of television are not displaced by 
online media. On the other hand, studies have shown that television has been partially displaced by newer forms of media (Ferguson \& Perse, 2000; Lee \& Kuo, 2002). Finally, research also shows that in general new media have not altered overall media use patterns, although some key differences have emerged (Kaye \& Johnson, 2003). To assess IM's influence on relevant media use patterns, Research Question 4 asks:

RQ4: Has instant messaging displaced the use of other media?

\section{Method}

\section{Participants and Procedures}

Participants were college students $(N=271)$ solicited from undergraduate communication courses who were given course credit for their participation. Participants were not pre-screened based on their technology use and 250 (92\%) respondents indicated they use instant messaging. The age of participants ranged from 18 to 27 years $(M=19.48, S D=1.40)$, with $85 \%$ between 18 and 20 years. Data were collected via a web-based questionnaire in April and May of 2004.

\section{Measures}

Respondents were asked to complete a questionnaire designed to assess their usage of five different communications technologies for satisfying 26 needs. Communication technologies represented channels examined in past studies that might be viewed as functional alternatives, that are relatively widespread among the target population, and that represent both traditional and contemporary channels, including email, face-to face communication, landline telephone, cell phone, and instant messaging. Twenty-six individual needs viewed as relevant across all channels (as delineated in the Results section) were derived from extant research on uses and gratifications of contemporary media (Ebersole, 2000; Flanagin \& Metzger, 2001). For each of the five channels, respondents were asked how often they used the technology to fulfill each of the listed needs, on a five-point Likert-type scale, where $1=$ "never" to $5=$ "always." Respondents were also given the opportunity to skip sections if they "never used" the technology in question.

The communication satisfaction of conversations held in IM was assessed by 16 applicable items based on Hecht's (1978) interpersonal communication satisfaction inventory, on a five-point Likert-type scale anchored by $1=$ "strongly disagree" and $5=$ "strongly agree."[2] Participants responded to items three separate times, prompted to think of conversations when they communicated with "one person through instant messaging" (Cronbach's $\alpha=0.86$ ), vs. conversations wherein they were "simultaneously communicating with $2-3$ persons" (Cronbach's $\alpha=0.89$ ) and when "simultaneously communicating with 4 or more persons" (Cronbach's $\alpha=$ 
0.90). Six items were reverse coded so that higher scores on all dimensions indicated greater communication satisfaction within their instant messaging conversations.

Media displacement was assessed by a question from Dimmick, Kline, and Stafford's (2000) study of the gratification niches of email. Participants were asked to estimate how their use of several communication technologies had changed since they began using instant messaging. Specifically, respondents were asked, since using instant messaging, if they had used other technologies "less," "about the same," or "more." Respondents were also given the option that the question may be "not applicable" if they did not use IM.

\section{Results}

To assess the primary needs fulfilled by instant messaging (RQ1), all items used to analyze the needs met by instant messaging were subjected to a principal axis factor analysis, using promax (oblique) rotation. Factors with eigenvalues greater than 1 were retained. Four factors were derived in this manner, explaining almost $67 \%$ of the variance overall: "Social Entertainment" [3] (to communicate easily, to do something convenient, to do something fun, to stay in touch, to be entertained, to find out interesting things, to pass time when bored, to get to know others, to provide information, to do something exciting, to do something with others, and to play; 54\% variance explained); "Task Accomplishment" (to learn how to do things, to solve problems, to gain insight into self and others, to generate ideas, to negotiate or bargain, to make decisions, to get people to do something for me, to impress people, and to learn about self and others; 7\% variance explained); "Social Attention" (to feel less lonely, to feel important, and to relax; 3\% variance explained); and "Meet New People" (to talk to people around the world and to meet new people; $3 \%$ variance explained).

To provide additional information for the assessment of RQ1, individual communication satisfaction scores were compared by repeated-measures univariate analyses of variance across communication channels (the within-subjects factor). In cases where the sphericity assumption was not met, the Huynh-Feldt correction was applied, and all post-hoc comparisons were performed using the Bonferrini adjustment. Table 1 contains the results of these analyses.

Research Question 2, which explored IM's relative (dis)advantages in needs fulfillment over other media, was assessed by a repeated-measures MANOVA. The type of communication technology used was specified as a within-subjects factor in GLM and the dependent variables were the mean scores on each of the four factors derived from $R Q 1$. Analyses indicated a significant multivariate effect for technology (Wilk's $\lambda=0.22, F(16,3132.06)=124.46, p \leq 0.001$, partial $\eta^{2}=0.31$ ). Follow up tests indicated differences in social entertainment scores $(F(4,254)=293.00, p \leq$ 0.001, partial $\eta^{2}=0.53$ ) among technologies, with channels arrayed in the following manner: face-to-face $(M=4.17, S D=0.54)$, cell phone $(M=3.90, S D=0.69)$, instant messaging $(M=3.79, S D=0.89)$, email $(M=3.14, S D=0.68)$, and landline 
Table 1 Mean Ratings (with standard deviations) and Cross-Media Comparisons of Needs Satisfaction $(N=248-258)$.

\begin{tabular}{|c|c|c|c|c|c|c|c|}
\hline Need & IM & E-mail & Landline Phone & Cell Phone & $\mathrm{FtF}$ & $F$ & Partial $\eta^{2}$ \\
\hline To communicate easily & $4.20(1.06)$ & $3.95(0.89)$ & $2.49(1.36)$ & $4.61(0.61)$ & $4.41(0.67)$ & 232.53 & 0.47 \\
\hline To stay in touch & $4.10^{\mathrm{a}}(1.02)$ & $4.02^{\mathrm{ab}}(0.94)$ & $2.55(1.34)$ & $4.41(0.73)$ & $3.82^{\mathrm{b}}(0.89)$ & 150.73 & 0.37 \\
\hline To do something convenient & $3.96^{\mathrm{ab}}(1.05)$ & $3.86^{\mathrm{ac}}(0.97)$ & $2.44(1.26)$ & $4.22(0.85)$ & $3.97^{\mathrm{bc}}(0.83)$ & 156.34 & 0.38 \\
\hline To do something fun & $3.93^{\mathrm{a}}(1.08)$ & $2.96(0.97)$ & $2.26(1.21)$ & $3.98^{\mathrm{a}}(0.96)$ & $4.38(0.65)$ & 237.98 & 0.48 \\
\hline To pass the time away when bored & $3.89^{\mathrm{a}}(1.12)$ & $2.90(1.18)$ & $2.20(1.23)$ & $3.65(1.10)$ & $3.87^{\mathrm{a}}(0.91)$ & 142.43 & 0.37 \\
\hline To be entertained & $3.86^{\mathrm{a}}(1.02)$ & $3.01(1.12)$ & $2.21(1.20)$ & $3.80^{\mathrm{a}}(1.02)$ & $4.29(0.70)$ & 211.86 & 0.45 \\
\hline To find out interesting things & $3.71^{\mathrm{a}}(1.11)$ & $3.09(1.02)$ & $2.24(1.19)$ & $3.83^{\mathrm{a}}(0.99)$ & $4.31(0.68)$ & 187.68 & 0.43 \\
\hline To provide information & $3.62^{\mathrm{a}}(0.98)$ & $3.67^{\mathrm{a}}(0.93)$ & $2.49(1.26)$ & $3.93^{\mathrm{b}}(0.81)$ & $4.04^{\mathrm{b}}(0.71)$ & 127.45 & 0.33 \\
\hline To get to know others & $3.58^{\mathrm{a}}(1.07)$ & $2.54(1.03)$ & $2.25(1.17)$ & $3.60^{\mathrm{a}}(0.99)$ & $4.38(0.63)$ & 243.04 & 0.49 \\
\hline To do something with others & $3.55^{\mathrm{a}}(1.08)$ & $2.72(1.15)$ & $2.25(1.19)$ & $3.65^{\mathrm{a}}(1.06)$ & $4.18(0.74)$ & 187.61 & 0.42 \\
\hline To do something exciting & $3.53(1.21)$ & $2.62(0.98)$ & $2.13(1.13)$ & $3.79(1.08)$ & $4.35(0.71)$ & 253.77 & 0.50 \\
\hline To play & $3.45^{\mathrm{a}}(1.20)$ & $2.36(1.07)$ & $1.97(1.10)$ & $3.35^{\mathrm{a}}(1.14)$ & $4.04(0.87)$ & 221.56 & 0.46 \\
\hline To relax & $3.39^{\mathrm{a}}(1.24)$ & $2.43(1.13)$ & $2.03(1.11)$ & $3.28^{\mathrm{a}}(1.19)$ & $3.70(0.94)$ & 140.65 & 0.36 \\
\hline To generate ideas & $3.28(1.17)$ & $2.74(1.11)$ & $2.04(1.07)$ & $3.46(1.06)$ & $4.10(0.67)$ & 186.68 & 0.42 \\
\hline To learn about myself and others & $3.25^{\mathrm{a}}(1.12)$ & $2.44(1.07)$ & $2.08(1.10)$ & $3.27^{\mathrm{a}}(1.13)$ & $4.16(0.73)$ & 200.00 & 0.44 \\
\hline To feel less lonely & $3.18(1.17)$ & $2.05^{\mathrm{a}}(1.04)$ & $2.09^{\mathrm{a}}(1.16)$ & $3.48(1.10)$ & $2.88(0.91)$ & 229.00 & 0.47 \\
\hline To get people to do something for me & $3.18(1.08)$ & $2.88(0.89)$ & $2.31(1.17)$ & $3.61^{\mathrm{a}}(0.91)$ & $3.64^{\mathrm{a}}(0.83)$ & 115.19 & 0.31 \\
\hline To solve problems & $3.05^{\mathrm{a}}(1.03)$ & $2.85^{\mathrm{a}}(1.00)$ & $2.27(1.14)$ & $3.55(0.92)$ & $3.95(0.73)$ & 140.00 & 0.36 \\
\hline To make decisions & $3.00(1.11)$ & $2.52(1.04)$ & $2.22(1.10)$ & $3.55(0.97)$ & $3.98(0.75)$ & 170.74 & 0.41 \\
\hline To learn how to do things & $2.99^{\mathrm{a}}(1.18)$ & $2.56(1.04)$ & $1.99(1.02)$ & $3.16^{\mathrm{a}}(1.11)$ & $4.01(0.74)$ & 175.19 & 0.41 \\
\hline To negotiate or bargain & $2.66(1.20)$ & $2.15^{\mathrm{a}}(1.04)$ & $2.03^{\mathrm{a}}(1.08)$ & $3.07(1.20)$ & $3.78(0.90)$ & 157.19 & 0.38 \\
\hline To gain insight into myself and others & $2.50(1.15)$ & $1.84^{\mathrm{a}}(0.87)$ & $1.83^{\mathrm{a}}(1.00)$ & $2.78(1.21)$ & $3.59(0.95)$ & 184.08 & 0.42 \\
\hline To meet new people & $2.38^{\mathrm{a}}(1.29)$ & $1.49^{\mathrm{b}}(0.81)$ & $1.54^{\mathrm{b}}(0.80)$ & $2.17^{\mathrm{a}}(1.22)$ & $4.06(0.82)$ & 366.40 & 0.59 \\
\hline To feel important & $2.37(1.19)$ & $1.88^{\mathrm{a}}(0.87)$ & $1.80^{\mathrm{a}}(0.97)$ & $2.75(1.19)$ & $3.26(1.06)$ & 145.71 & 0.36 \\
\hline To talk to people around the world & $2.34^{\mathrm{a}}(1.33)$ & $1.78^{\mathrm{b}}(1.02)$ & $1.55(0.82)$ & $1.86^{\mathrm{b}}(1.13)$ & $2.50^{\mathrm{a}}(1.14)$ & 46.01 & 0.15 \\
\hline To impress people & $2.24(1.16)$ & $1.73^{\mathrm{a}}(0.89)$ & $1.74^{\mathrm{a}}(0.95)$ & $2.50(1.17)$ & $3.34(0.99)$ & 167.80 & 0.39 \\
\hline
\end{tabular}

To do something convenient

To pass the time away when bored

$3.96^{\mathrm{ab}}(1.05)$

$2.55(1.34)$

To be entertained

To find out interesting thing

$3.71^{\mathrm{a}}(1.11)$

$3.09(1.02)$

$2.24(1.19)$

$3.62^{\mathrm{a}}(0.98) \quad 3.67^{\mathrm{a}}(0.93)$

$2.49(1.26)$

$3.55^{\mathrm{a}}(1.08)$

$2.25(1.19)$

$2.13(1.13)$

$3.93^{\mathrm{b}}(0.81)$

$3.79(1.08)$

$2.04(1.07)$

$2.08(1.10)$

$2.09^{\mathrm{a}}(1.16)$

$.31(1.17)$

$2.27(1.14)$

$3.18(1.17)$

$2.88(0.89)$

$3.05^{\mathrm{a}}(1.03)$

$2.52(1.04)$

$1.99(1.02)$

$2.15^{\mathrm{a}}(1.04)$
$1.84^{\mathrm{a}}(0.87)$

$1.49^{\mathrm{b}}(0.81)$

$1.73^{\mathrm{a}}(0.89)$

$1.74^{\mathrm{a}}(0.95)$

$2.50(1.17)$

$3.34(0.99)$

Notes: 1 =low use, 5 =high use. Means with the same letter in the superscript within the same row are not significantly different from one another; all significant differences are at the $p<0.05$ level. 
telephone $(M=2.30, S D=1.10)$. Mean values on social entertainment were significantly different between all technologies at $p \leq 0.001$ except for those between the cell phone and IM, which did not differ from each other. Scores on task accomplishment $\left(F(4,254)=274.15, p \leq 0.001\right.$, partial $\left.\eta^{2}=0.52\right)$ differed significantly, such that mean values were ordered as follows: face-to-face $(M=3.84, S D=$ $0.58)$, cell phone $(M=3.22, S D=0.84)$, instant messaging $(M=2.91, S D=0.90)$, email $(M=2.41, S D=0.70)$, and landline telephone $(M=2.06, S D=0.95)$. All means differed from each other at the $p \leq 0.001$ level. Social attention $(F(4,254)=$ 231.26, $p \leq 0.001$, partial $\left.\eta^{2}=0.47\right)$ scores differed significantly across channels, where mean values were face-to-face $(M=3.61, S D=0.79)$, cell phone $(M=3.17$, $S D=0.99)$, instant messaging $(M=2.98, S D=1.03)$, email $(M=2.12, S D=0.86)$, and landline telephone $(M=1.97, S D=1.01)$, all of which were significantly different $(p<0.001)$ except email and landline telephones, which were not significantly different from one another. Finally, scores on to meet new people $(F(4,254)=210.11$, $p \leq 0.001$, partial $\left.\eta^{2}=0.45\right)$ were significantly different, as follows: face-to-face $(M=$ $3.28, S D=0.78)$, instant messaging $(M=2.36, S D=1.19)$, cell phone $(M=2.02$, $S D=1.04)$, email $(M=1.64, S D=0.80)$, and landline telephone $(M=1.55, S D=$ $0.73)$. All means differed significantly from one another $(p<0.01)$, except those of email and landline telephones. Figure 1 provides an overview of these findings.

To examine Research Question 3, a repeated measures univariate analysis of variance was conducted on communication satisfaction scores reported by participants for one-person, two- and three-person, and four or more person conversations using instant messaging (the within-subjects factor). The sphericity assumption was

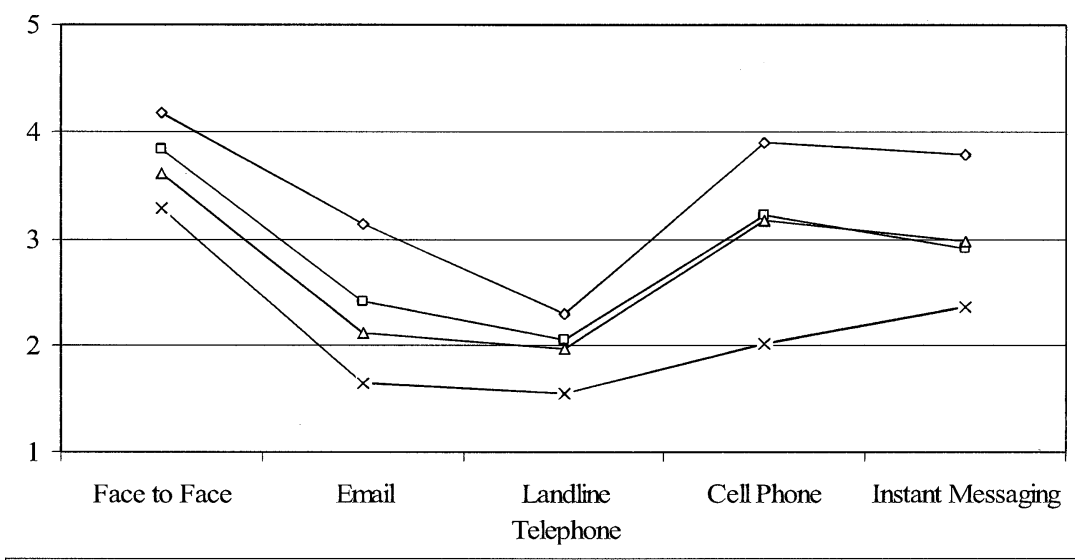

$\multimap$ Social Entertainment $\rightarrow-$ Task Accomplishment $\rightarrow-$ Social Attention $-x-$ Meet New People

Figure 1 Mean Factor Value by Channel.

Notes: All mean values within each factor vary at the $p<0.001$ level, except the following: cell phone and IM (social entertainment); email and landline telephones (social attention); e-mail and landline telephones (meet new people), which were not significantly different from one another. Cell phones and IM differed at the $p<0.01$ level for the factor to meet new people. 
not met so the Huynh-Feldt correction was applied. The main effect of number of conversations was significant $\left(F(1.72,410.39)=55.96, p<0.001\right.$, partial $\left.\eta^{2}=0.19\right)$. Post-hoc comparisons were performed using the Bonferrini adjustment for multiple comparisons, which showed that means between one-person $(M=4.28, S D=.56)$ and two to three-person $(M=4.25, S D=0.85)$ conversations on IM did not differ from one another, although both of these were significantly more satisfying than conversations involving four or more persons $(M=3.82, S D=0.89 ; p<0.001)$.

Data to assess Research Question 4 showed mixed evidence for media displacement coinciding with IM use. Since using instant messaging, 71\% reported using landline telephones less (27\% same, $2 \%$ more) and $38 \%$ reported using email less, although $47 \%$ reported using email about the same amount (15\% more). Face-to-face communication was used about the same amount by $74 \%$ of respondents, and cell phones were used less by $24 \%$, the same by $53 \%$, and more by $23 \%$. T-tests comparing usage means against the scale midpoint of two indicated that both email $(t(516)=-5.36, p<0.001)$ and landline telephones $(t(461)=-22.30, p<0.001)$ were used significantly less than they were prior to IM usage.

\section{Discussion}

The four factors of IM use that emerged in this study in many ways parallel those found in the limited research to date that has considered motivations for using IM. "Social entertainment" items from this study are largely consistent with the "sociability gratifications" discovered by Ramirez et al. (2004), the "social usefulness" dimensions of facilitating friendships, obtaining personalized communication, and ease of use noted by Huang and Yen (2003), and the "entertainment" items discussed by Leung (2001). In addition, the "task accomplishment" factor in this study is similar to convenience and utilitarian items from past research (e.g., so-called "gratification opportunities," Ramirez et al., 2004), as are the "social attention" (similar to "inclusion" items from Leung, 2001) and "meet new people" motivations (similar to "sociability" items from Leung, 2001, including "to meet people" and making friends). Thus, some consistencies of motivations for using IM are beginning to emerge across research studies that collectively provide insight into the current usage of this increasingly important communication tool.

Results of this study also suggest important differences among technologies. Faceto-face communication $(\mathrm{FtF})$ was by far the most useful and most versatile channel for need satisfaction, suggesting that despite a growing number of increasingly complex and powerful media choices, nothing appears to compare to face-to-face communication in terms of satisfying individuals' communication, information, and social needs (Elliott \& Quattlebaum, 1979; Flaherty et al., 1998; Flanagin \& Metzger, 2001; Perse \& Courtright, 1993; Rice, 1993). By contrast, landline phones were by far the least useful for need satisfaction, reflecting this tool's diminished importance among users in this study. Indeed, landline telephones ranked lowest on all use factors (though they did not differ significantly from email for social attention or for 
meeting new people). Email was also generally rated low on needs satisfaction. For instance, both cell phones and IM were used significantly more than email for all needs satisfaction factors, consistent with recent research showing that IM is viewed as more effective than email for both utilitarian and social uses (Ramirez et al., 2004).

Consideration of the cross-media comparisons of the individual communication satisfaction scores (versus the factors) supports these findings: FtF was rated highest of all channels on 18 of the 26 needs; IM was rated significantly higher than email on 22 of the 26 needs, and cell phones were rated significantly higher than email for 25 of these needs; and cell phones and IM were both rated significantly higher than landline phones on all needs [4], while email was rated higher than landline phones for 20 of 26 needs.

Overall, differences between IM and cell phones were the least dramatic, indicating higher functional equivalence between these media. Although the only needs items for which IM was rated significantly higher than cell phones were to pass the time away when bored and to talk to people around the world, the social entertainment factor overall did not differ significantly between IM and cell phones. Moreover, cell phones were used significantly more for task accomplishment and social attention, whereas IM was used more to meet new people. Notably, cell phones scored quite high on ease of communication needs (e.g., to communicate easily) as well as the need to feel less lonely, indicating a high utility for maintaining interpersonal relationships, a relational aspect not captured explicitly in the derived usage factors. Thus, although high in functional equivalence, cell phones appear to be used more to maintain existing relations and accomplish tasks, whereas IM might enjoy greater use for establishing new relationships, particularly when interactants are nonproximate.

Further research in the U\&G tradition that links beliefs to gratifications sought to gratifications obtained, or that focuses explicitly on the "social and psychological circumstances of media use" is necessary to unpack these differences more fully (Rubin, 2002, p. 532). Future research, for example, could determine which individual traits or circumstances (e.g., past exposure, psychological factors, media dependencies) lead to beliefs about the efficacy of these tools, and that might result in a (mis)match between gratifications sought and obtained. The degree of match, in turn, could be valuable in predicting both the nature and the extent of subsequent use. Particularly with newer media in the early stages of diffusion, the U\&G perspective is well-suited to investigate these issues (Ruggiero, 2000).

College-age respondents in this study exhibited a high capacity for multi-tasking in IM conversations, evidenced by the equivalent perceived satisfaction of conversations with one other person vs. those with two to three other persons. However, IM conversations also appear to exhibit an upper limit of four or more simultaneous conversations, past which respondents reported significantly less conversational satisfaction. Thus, although IM displays fairly robust concurrency (Valacich et al., 1993), the medium's ability to support distinct communication events simultaneously without detracting from others degrades past a point. Future research could compare this concurrency level with other communication channels to arrive at a relative 
comparison of IM on this dimension, and might seek to establish the individual psychological characteristics of users that make them more or less prone to take advantage of concurrency.

Results also showed displacement effects that coincided with the use of IM. However, an important limitation of this study is its cross-sectional design, which severely limits the ability to conclude that displacement effects are due to increased IM use over time. Alternatively, reduction in the usage of communication technologies might have occurred either absent the introduction of IM or due to the use of communication tools other than IM. With this limitation in mind, it does appear plausible to tentatively conclude that reductions in email usage are in part dependent on increased IM usage, given these tools' apparent direct competition with one another. Reductions in landline telephone usage, on the other hand, are more likely to be a historical artifact, and/or linked to increased cell phone diffusion. Future research invoking over-time research designs are required to sort out these distinctions. Nonetheless, coupled with the needs data, findings from this study suggest that IM is making significant strides toward replacing email. Although speculative, it may be that the potentially synchronous nature of IM accounts for needs ratings higher than those for email, as well as for its partial displacement.

Overall, results of this study shed considerable light on the use of IM-largely neglected to date in the CMC literature - within what is currently among the largest demographic groups utilizing this tool, college students. Findings indicate that in its short lifespan IM has become a central communication tool within this population, being used to satisfy a variety of needs, and utilized quite heavily relative to other forms of mediated communication. Moreover, evidence suggests that IM users are satisfied with carrying on multiple simultaneous conversations (up to a point), and that IM might be displacing email usage in consequential ways. As college-age users graduate to workplace environments, and as younger IM users assume a higher proportion of $\mathrm{CMC}$ users overall, findings from this study will become increasingly important for contextualizing the use of IM in the contemporary media environment.

\section{Notes}

[1] IM was launched in late-1996 with the introduction of free, user-friendly IM utilities (Huang \& Yen, 2003; Tyson, 2004). IM enables users to send synchronous or asynchronous messages, within an environment that includes additional features such as utilities to provide detailed personal profiles, alerts and lists about other users' on- or off-line status, file sharing, emoticons, microphones, and web cameras (for more details see Tyson, 2004).

[2] Specifically, the following items were used (asterisks indicate reverse-coded items): The other person let me know that I was communicating effectively; nothing was accomplished*; I would like to have another conversation like this one; the other person genuinely wanted to get to know me; I was very dissatisfied with the conversation*; during the conversation I was able to present myself as I wanted the other person to view me; I was very satisfied with the conversation; the other person expressed a lot of interest in what I had to say; I did not enjoy the conversation*; the other person did not provide support for what he/she was saying*; 
I felt I could talk about anything with the other person; we each got to say what we wanted; I felt that we could laugh easily together; the conversation flowed smoothly; the other person frequently said things which added little to the conversation*; we talked about something I was not interested in*.

[3] "Social entertainment" seems to capture the spirit of the items in this factor best, given the presence of elements of both socializing and entertainment. Unlike TV viewing, for example, the entertainment gratification gleaned from IM is explicitly social, since IM use cannot occur alone.

[4] These results contrast findings by Ramirez et al. (2004), possibly because of a more recent data collection in the present study, who found that (a) landline phones were considered equal to IM on "gratification opportunities" (i.e., for utilitarian purposes and for the sake of convenience) and (b) IM was rated as significantly lower than landline phones on sociability factors.

\section{References}

Dimmick, J., Kline, S., \& Stafford, L. (2000). The gratification niches of personal e-mail and the telephone: Competition, displacement, and complementarity. Communication Research, 27, 227-248.

Ebersole, S. (2000). Uses and gratification of the web among students. Journal of Computermediated Communication, 6, unpaginated. Retrieved July 28, 2004 from: http://www.ascusc. org/jcmc/vol6/issue1/ebersole.html.

Elliot, W. R., \& Quattlebaum, C. P. (1979). Similarities in patterns of media use: A cluster analysis of media gratifications. Western Journal of Speech Communication, 43, 61-72.

Ferguson, D. A., \& Perse, E. M. (2000). The World Wide Wed as a functional alternative to television. Journal of Broadcasting \& Electronic Media, 44, 155-174.

Flaherty, L. M., Pearce, K. J., \& Rubin, R. B. (1998). Internet and face-to-face communication: Not functional alternatives. Communication Quarterly, 46, 250-268.

Flanagin, A. J., \& Metzger, M. J. (2001). Internet use in the contemporary media environment. Human Communication Research, 27, 153-181.

Graham, J. (2003, October 20). Instant messaging program are no longer just for messages. USA Today, p. 5D.

Hecht, M. (1978). Measures of communication satisfaction. Human Communication Research, 4, $350-368$.

Huang, A. H., \& Yen, D. C. (2003). Usefulness of instant messaging among young users: Social vs. work perspective. Human Systems Managements, 22, 63-72.

Katz, E, Blumler, J. G., \& Gurevitch, M. (1974). Utilization of mass communication by the individual. In J. G. Blumler \& E. Katz (Eds.), The uses of mass communications: Current perspectives on gratifications research (pp. 19-32). Beverly Hills, CA: Sage.

Katz, E., Gurevitch, M., \& Haas, H. (1973). On the use of the mass media for important things. American Sociological Review, 38, 164-181.

Kayany, J. M., \& Yelsma, P. (2000). Displacement effects of online media in the socio-technical contexts of households. Journal of Broadcasting \& Electronic Media, 44, 215-229.

Kaye, B. K. (1998). Uses and gratifications of the Word Wide Web: From couch potato to web potato. New Jersey Journal of Communication, 6, 21-40.

Kaye, B. K., \& Johnson, T. J. (2002). Online and in the know: Uses and gratifications of the Web for political information. Journal of Broadcasting \& Electronic Media, 46, 54-71.

Kaye, B. K., \& Johnson, T. J. (2003). From here to obscurity?: Media substitution theory and traditional media in an on-line world. Journal of the American Society for Information Science and Technology, 54, 260-273. 
Lee, W., \& Kuo, E. C. Y. (2002). Internet and displacement effect: Childrens media use and activities in Singapore. Journal of Computer-Mediated Communication, 7, unpaginated. Retrieved August 11, 2004 from: http://www.ascusc.org/jcmc/vol7/issue2/singapore.html.

Lee, B.-K., \& Lee, W. (2004). The effect of information overload on consumer choice quality in an on-line environment. Psychology \& Marketing, 21(3), 159-183.

Leung, L. (2001). College student motives for chatting on ICQ. New Media \& Society, 3, 483-500.

Lichtenstein, A., \& Rosenfeld, L. B. (1983). Uses and misuses of gratifications research: An explication of media functions. Communication Research, 10, 97-109.

Lichtenstein, A., \& Rosenfeld, L. B. (1984). Normative expectations and individual decisions concerning media gratifications choices. Communication Research, 11, 393-413.

Mello, A. (2002). Instant messaging, instant service. Retrieved 2 August 2004 from: http:// techupdate.zdnet.com/techupdate/stories/main/0,14179,2865520,00.html.

Metzger, M. J., \& Flanagin, A. J. (2002). Audience orientations toward new media. Communication Research Reports, 19, 338-351.

Nielsen//NetRatings (2002a). More than 72 percent of the U.S. online population uses internet applications, according to Nielsen//NetRatings. Retrieved 5 August 2004 from http:// www.nielsen-netratings.com/pr/pr_021218.pdf.

Nielsen//NetRatings (2002b). Nearly 20 percent of the active online population are kids and teens, creating opportunities for marketers, according to Nielsen//NetRatings. Retrieved 5 August 2004 from http://direct.www.netratings.com/pr/pr_020813.pdf.

Oliva, R. A. (2003). Instant messaging comes of age. Marketing Management, 12(3), 49.

Perse, E. M., \& Courtright, J. A. (1993). Normative images of communication media: Mass and interpersonal channels in the new media environment. Human Communication Research, 19, 485-503.

Peter, J., Schouten, A., \& Valkenburg, P. M. (May, 2004). Adolescents' identity experiments on the Internet. Paper presented at the Annual Meetings of the International Communication Association, New Orleans, LA.

Pew Research (2001). Teenage life online: The rise of the instant message generation and the Internet's impact on friendships and family relationships. Retrieved 4 December 2003 from: http://www.pewinternet.org/reports/pdfs/PIP_teens_report.pdf.

Pew Research (2003). America's online pursuits: The changing picture of who's online and what they do. Retrieved 15 July 2004 from: http://www.pewinternet.org/pdfs/PIP_Online_ Pursuits_Final.PDF.

Radicati Group (2003). Instant Messaging and Presence Market Trends, 2003-2007. Retrieved 5, August 2004 from http://www.researchandmarkets.com/reportinfo.asp?report_id $=35248$ $\& \mathrm{t}=$ e\&cat_id $=4$.

Ramirez, A. R., Dimmick, J., \& Lin, S. (May, 2004). Revisiting media competition: The gratification niches of instant messaging, e-mail, and telephone. Paper presented at the Annual Meetings of the International Communication Association, New Orleans, LA.

Rennecker, J., \& Godwin, L. (2003). Theorizing the unintended consequences of instant messaging productivity. Sprouts: Working Papers on Information Environments. Systems and Organizations, 3. Retrieved 30 July 2004 from: http://weatherhead.cwru.edu/sprouts/2003/ 030307.pdf.

Rice, R. E. (1993). Media appropriateness: Using social presence theory to compare traditional and new organizational media. Human Communication Research, 19, 451-484.

Rubin, A. M. (2002). The uses-and-gratifications perspective of media effects. In J. Bryant \& D. Zillmann (Eds.), Media effects: Advances in theory and research (2nd ed.) (pp. 525-548). Mahwah, NJ: Erlbaum.

Rubin, A. M., \& Rubin, R. C. (1985). Interface of personal and mediated communication: A research agenda. Critical Studies in Mass Communication, 2, 36-53. 
Ruggiero, T. E. (2000). Uses and gratifications theory in the 21st Century. Mass Communication \& Society, 3, 3-37.

Swartz, N. (2003). Instant messaging goes corporate. Information Management Journal, 37(4), 8.

Tewksbury, D., \& Althaus, S. L. (2000). An examination of motivations for using the world wide web. Communication Research Reports, 17, 127-138.

Tyson, J. (2004). How instant messaging works. Retrieved 28 July 2004 from: http://computer. howstuffworks.com/instant-messaging.htm.

Valacich, J. S., Paranka, D., George, J. F., \& Nunamaker, J. F. (1993). Communication concurrency and the new media: A new dimension for media richness. Communication Research, 20, 249276.

Whelan, D. (2001). The instant messaging market. American Demographics, 23(12), 28-31. 